\title{
PROMOTION OF HUMAN RIGHTS BY PROVIDING EQUAL EMPLOYMENT OPPORTUNITIES FOR THE DISADVANTAGED WORKERS IN ASEAN
}

\author{
Fumitaka Furuoka ${ }^{a+}$ \\ Beatrice Lim $^{b}$ \\ Khairul Hanim Pazim ${ }^{b}$ \\ ${ }^{a} A$ sia-Europe Institute, University of Malaya \\ 50603 Kuala Lumpur, Malaysia \\ ${ }^{b}$ Faculty of Business, Economics and Accountancy, \\ Universiti Malaysia Sabah \\ 88400, Kota Kinabalu, Sabah, Malaysia \\ ${ }^{+}$Corresponding author: fumitaka@um.edu.my
}

\begin{abstract}
${ }^{1}$ The promotion and protection of human rights is a key political principle of ASEAN and the ASEAN member states have made efforts to safeguard human rights and freedom of all ASEAN citizens, including the disadvantaged workers. This paper examines the ASEAN countries' commitment and labour policy to promote equal employment opportunities for women, the elderly and persons with disabilities. The findings of this study would provide better insights to the issues of human rights in the labour market among ASEAN countries. It can serve as a resource for researchers, practitioners and policymakers for policymaking in ensuring that disadvantaged workers are not excluded from being able to fully enjoy their right to work as their participation in the labour market could in turn be one of the solutions to reduce high unemployment rate suffered in some ASEAN countries.
\end{abstract}

Key words: Disadvantaged workers, gender equality, aging society, persons with disabilities, ASEAN

\section{Introduction}

The promotion of human rights, freedom democracy and rule of law is a key political principle of ASEAN. ASEAN member countries have made efforts to safeguard human rights and freedom of all ASEAN citizens including disadvantaged workers (ASEAN, 2018a). In this context, the leaders of the ASEAN member countries adopted the ASEAN Human Rights Declaration (AHRD) in 2012 and the fourth general principle of the AHRD clearly declared, "The rights of women, children, the elderly, persons with disabilities, migrant workers and vulnerable and marginalised groups are an inalienable, integral and indivisible pars of human rights and fundamental freedom"(ASEAN, 2013a). More importantly, ASEAN leaders have endorsed and affirmed the clause of the Universal Declaration of Human Rights (UDHR) on

\footnotetext{
${ }^{1}$ This study was conducted as part of the Jean Monnet Center of Excellence project (Project Number: $586907-$ EPP-1-2017-1-MY-EPPJMO-CoE). The empirical analysis is conducted by using EViews. The data and EViews code are available at https://sites.google.com/site/fumitakafuruokawebpage2/home/paper-12
} 
the economic, social and cultural rights and declared in the AHRD, "Every person has the right to work" (ASEAN, 2014).

In order to promote basic human rights of the vulnerable groups, ASEAN came up with specific plans for women, the elderly and persons with disabilities. First of all, ASEAN decided to set up the ASEAN commission on promotion and protector of the rights of women and children (ACWC) in 2010. There are two inter-related objectives for the ACWC. The first objective is to promote and protect human rights of women and children. The second objective is to achieve gender equality and empowerment of women (ASEAN, 2018b). ACWC released a progress report in 2019. In the report, the ACWC officially expressed its serious concern about gender inequality in ASEAN countries. For example, there is a persistent gender gap in economic participation among ASEAN countries. This is basically due to the gender gap in human capital investment and labour market discrimination. Another problem in the labour market is that women tended to dominate vulnerable employment, such as part-time employment, temporary employment and informal employment.

Secondly, there is an increasing awareness that ASEAN countries have faced some problems related to the ageing society such as sustainability of public pension system or lack of young workers. In order to cope with this problem, ASEAN adopted the ASEAN strategic framework on social welfare and development in 2015. In this framework, ASEAN will make efforts to "promote regional cooperation initiative to support ASEAN countries to be well-prepared for the ageing society". More significantly, ASEAN has promoted the idea of "productive ageing". ASEAN declares that one of the main objectives in its strategic plan for the social welfare is "healthy, active and productive ageing is promoted in an enabling and supportive environment" (ASEAN, 2015).

Thirdly, ASEAN countries made serious commitment on the promotion of the disability rights by ratifying the UN Convention on the rights of persons with disabilities (CRPD). In other words, ASEAN countries would "recognise the rights of person with disability to work, on an equal basis with other". It also means that ASEAN countries would recognise the rights of a person with disabilities to "the opportunity to gain a living by work freely chosen or accepted in a labour market". The ratification of the CRPD also would induce ASEAN countries to "safeguard and promote the realisation of the right to work" and "to prohibit discrimination on the basis of disability" (United Nations, 2006).

Despite its importance, the promotion of equal employment opportunities for the disadvantaged workers is still an overlooked topic pertaining labour market. Thus, this paper examines how ASEAN countries have made efforts to promote employment for women, older people and persons with disabilities. There are two research questions in the current study. The first research question is: what is the current status of employment among the disadvantaged workers in ASEAN countries? The second research question is: what is the main labour policy to promote employment for them?

This paper consists of five parts. Following this introductory part, the second section explains the main characteristics of labour markets in the ASEAN countries. The third section discusses the promotion of gender equality. The fourth section explains the promotion of productive ageing by providing job opportunities for the elderly. The fifth section discusses the promotion of employment among persons with disabilities. The final section consists of the conclusion.

\section{Labour market condition and unemployment in ASEAN}

The conditions and situations of a labour market could be examined by the relationship between unemployment and inflation rates. For example, the unemployment rate indicates a balance 
between labour supply and demand. If labour supply is largely greater than labour demand, there would be a higher unemployment rate. The unemployment rates in ASEAN countries for the period of 1995 to 2017 are depicted in Figure 1 and the main indicators of unemployment are reported in Table 1. As Figure 1 clearly indicates, two ASEAN countries, namely Brunei and Indonesia, suffered from high unemployment problem. ${ }^{2}$ The average unemployment rate in Brunei was 6.3 percent between 1995 and 2017. The country's unemployment rates are-were around 5 percent from 1995 to 2008. Its unemployment rate jumped up from 6.8 percent in 2012 to 7.7 percent in 2015 and increased further to 9.3 percent in 2017. Indonesia's unemployment rate increased from 3.9 percent in 1995 to 5.4 percent in 1998 and increased further to 6.0 percent in 2000. The unemployment rate declined further to 7.9 percent in 2005 . The labour market condition in Indonesia showed some improvement after 2010. Its unemployment rate decreased from 5.6 percent in 2010 to 4.3 percent in 2013, and further to 4.1 percent in 2017. Among the ASEAN countries, Malaysia, Philippines and Singapore have moderate unemployment rates and their average unemployment rates are around 3 percent. Malaysia's unemployment rate increased slightly from 3.1 percent in 1995 to 3.4 percent in 1999 and increased further to 3.6 percent in 2004. Its unemployment rate increased again from 3.0 percent in 2012 to 3.1 percent in 2015, increased slightly to 3.4 percent in 2017 . By contrast, the unemployment rate in the Philippines decreased from 4.0 percent in 2007 to 3.6 percent in 2010 and declined further to 2.5 percent in 2017. Similarly, Singapore's unemployment rate decreased from 5.8 percent in 2009 , to 4.1 percent in 2010, before settling at 3.9 percent in 2017. It is interesting to note that unemployment rates in five countries in mainland Southeast Asia are lower than in the other ASEAN countries. The average unemployment rate in these countries are lower than 2 percent. The unemployment rate in Cambodia decreased from 1.5 percent in 2005 to 1.3 percent in 2009 , and further to 1.0 percent in 2017. In Lao, its unemployment rate was constantly lower than 1 percent in the 2010s. In the case of Myanmar, its unemployment rate slightly increased from 0.9 percent in 2010 to 1.1 percent in 2016 and rose further to 1.5 percent in 2017. Thailand's unemployment rate decreased from 2.6 percent in 2001 to 1.0 percent in 2009 and decreased further to 0.6 percent in 2017. In the case of Vietnam, its unemployment rate decreased from 2.7 percent in 2001 to 2.3 percent in 2008 and declined further to 1.8 percent in 2017.

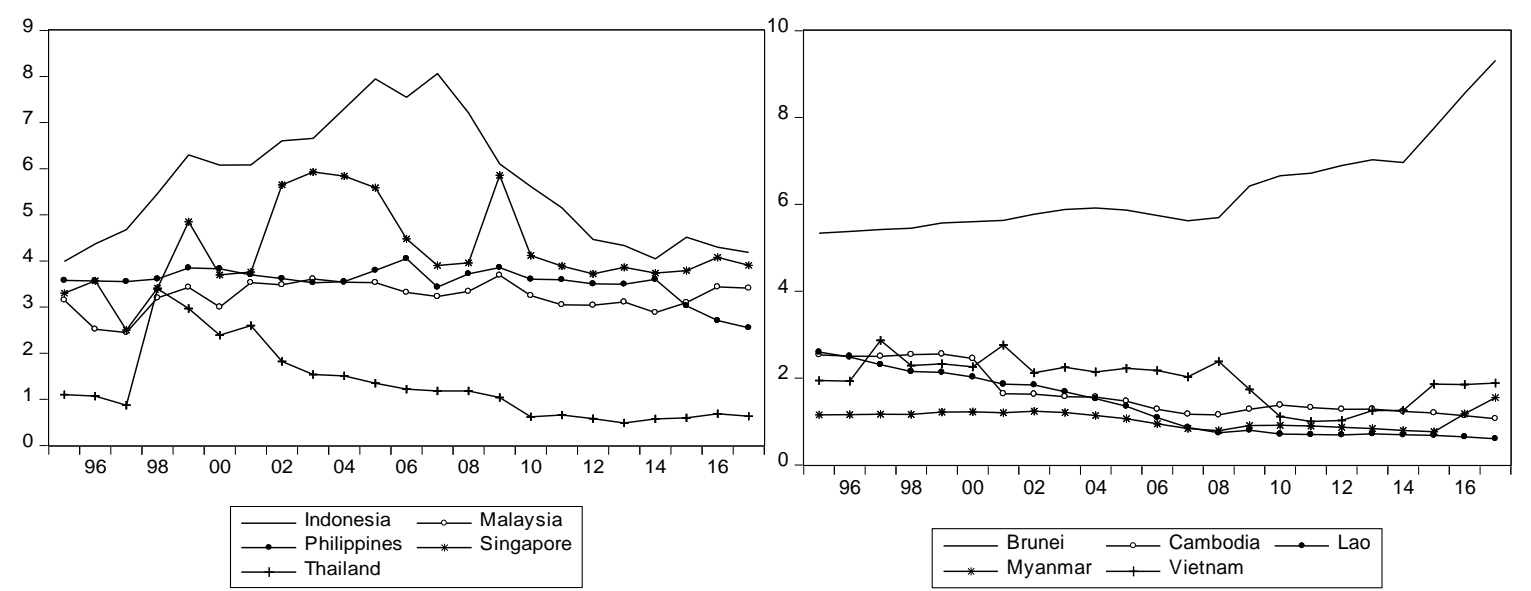

Figure 1: Unemployment rates in ASEAN

\footnotetext{
${ }^{2}$ The quality of data on unemployment rate in the ASEAN countries could be questionable. Firstly, unemployment rate could be under-estimated, especially some new member states, such as Cambodia, Laos and Myanmar. Secondly, there are no standard measurement for unemployment rate among the ASEAN countries. Thus, International Labour Organization (2019) recently reported the problems of measurement for unemployment rates.
} 


\begin{tabular}{|c|c|c|c|c|}
\hline Countries & Mean & Maximum & Minimum & $\begin{array}{c}\text { Standard } \\
\text { deviation }\end{array}$ \\
\hline Brunei & 6.3 & 9.3 & 5.3 & 1.0 \\
\hline Indonesia & 5.6 & 8.0 & 3.9 & 1.3 \\
\hline Cambodia & 1.6 & 3.5 & 1.0 & 0.5 \\
\hline Lao & 1.3 & 2.6 & 0.6 & 0.6 \\
\hline Malaysia & 3.2 & 3.6 & 2.4 & 0.3 \\
\hline Myanmar & 1.0 & 1.5 & 0.7 & 0.1 \\
\hline Philippines & 3.3 & 4.0 & 2.5 & 0.3 \\
\hline Singapore & 4.2 & 5.9 & 2.7 & 0.9 \\
\hline Thailand & 1.3 & 3.4 & 0.4 & 0.8 \\
\hline Vietnam & 1.9 & 2.8 & 0.9 & 0.5 \\
\hline
\end{tabular}

Table 1: Main indicators of unemployment in ASEAN

On the other hand, labour demand is a derived demand. An increase in the demand of products would cause an increase in labour demand. In this sense, the inflation rate can indicate a balance between product demand and supply. If the money supply is constant and product demand is largely greater than the product supplied, there are higher inflation rates. The inflation rate in ASEAN countries for the period of 1995 to 2017 depicted in Figure 2 and the main indicators of inflation are reported Table 2. As the figure clearly indicates, four ASEAN countries, namely Indonesia, Lao, Myanmar and Vietnam, suffered from high inflation problems. Due to the Asian economic crisis in the end of the 1990s, Indonesia's inflation rate was 19.9 percent in 1998 and decreased to 5.0 percent in 2001. The country's inflation rate increased again from 3.5 percent in 2004 to 9.0 percent in 2006 . In the case of Lao, inflation rate rapidly increased from 1.9 percent in 1997 to 8.1 percent in 1998 and rose further to 21.4 percent in 1999 . The country's inflation rate increased again from 3.7 percent in 2001 to 5.5 percent in 2002, further to 8.8 percent in 2003. Myanmar's inflation rate also increased rapidly from 3.8 percent in 2005 to 8.9 percent in 2006 and rose further to 18.7 percent in 2008 . The inflation rate in the country increased again from 1.5 percent in 2012 to 5.6 percent in 2014, further to 11.2 percent in 2015 . In the case of Vietnam, its inflation rate jumped from 4.5 percent in 2005 to 16.1 percent in 2008, further to 18.6 percent in 2011. Among the ASEAN countries, Cambodia and the Philippines have moderate inflation rate and their average inflation rates are around 3 percent. In the case of Cambodia, its inflation rate increased rapidly from 4.1 percent in 2006 to 19.3 percent in 2008 and decreased to 3.8 percent in 2010. The country's inflation rate in 2010s were around 3 percent. In the case of the Philippines, its inflation rate increased slightly from 2.4 percent in 2004 to 4.3 percent in 2006 and increased further to 7.0 percent in 2008 . The central banks in three ASEAN countries, namely Malaysia, Singapore and Thailand, have successfully managed to keep inflation low. Their average inflation rates are around 3 percent. Malaysia's inflation increased slightly from 1.9 percent in 2004 to 3.1 percent in 2006 and rose further to 5.0 percent in 2008. Similarly, inflation rate in Thailand increased slightly from 2.2 percent in 2004 to 4.0 percent in 2006, and further to 5.0 percent in 2008. Singapore's inflation increased from 0.5 percent in 2009 to 2.7 percent in 2010, and further to 5.3 percent in 2011. It should be noted that the problem of the price level in Brunei is not inflation, but deflation. 
The country suffered from deflation from 1998 to 1999. In 2002, the price level in the country decreased by 2.2 percent. Brunei suffered again a prolonged deflation from 2014 to 2017.

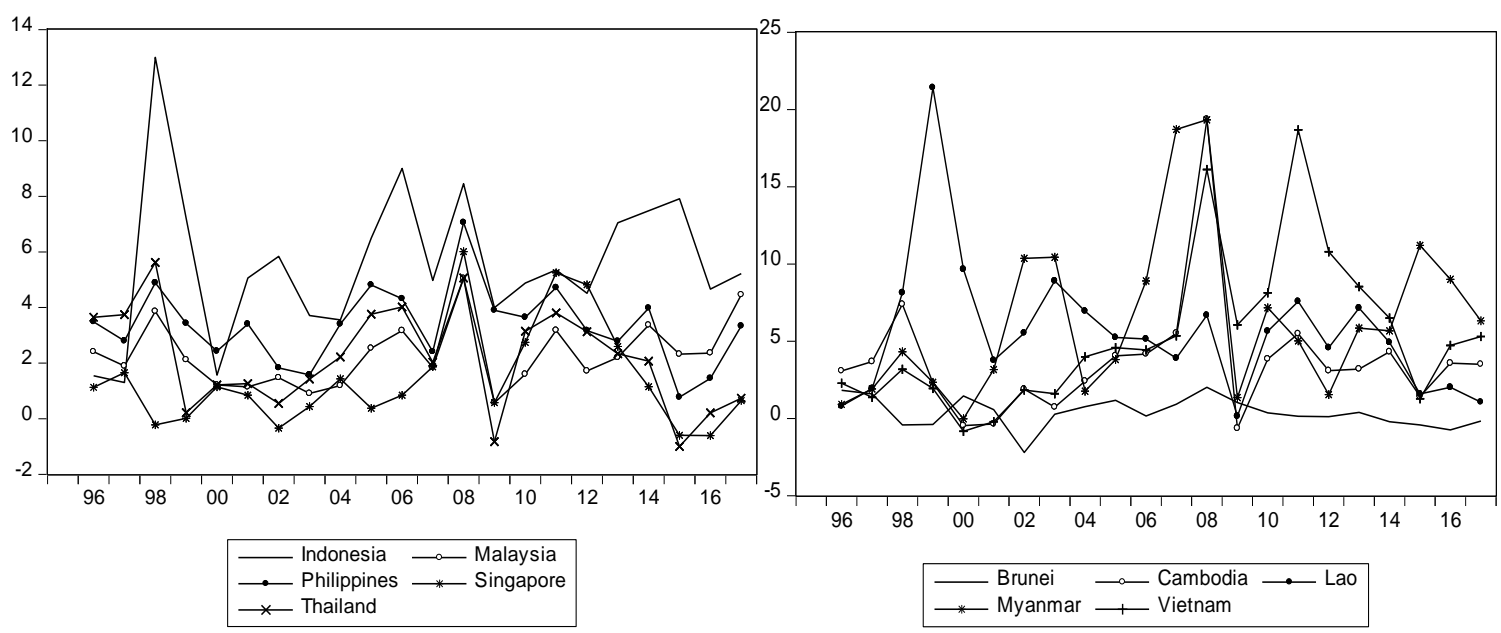

Figure 2: Inflation rates in ASEAN

\begin{tabular}{|c|c|c|c|c|}
\hline Countries & Mean & Maximum & Minimum & $\begin{array}{c}\text { Standard } \\
\text { deviation }\end{array}$ \\
\hline Brunei & 0.3 & 2.0 & -2.2 & 0.9 \\
\hline Indonesia & 5.5 & 12.9 & 1.3 & 2.7 \\
\hline Cambodia & 3.7 & 19.3 & -0.6 & 4.0 \\
\hline Lao & 5.5 & 21.4 & 0.1 & 4.4 \\
\hline Malaysia & 2.2 & 5.0 & 0.5 & 1.1 \\
\hline Myanmar & 6.3 & 19.3 & -0.6 & 5.3 \\
\hline Philippines & 3.1 & 7.0 & 0.7 & 1.3 \\
\hline Singapore & 1.4 & 6.0 & -0.6 & 1.8 \\
\hline Thailand & 2.1 & 5.6 & -1.0 & 1.8 \\
\hline Vietnam & 5.2 & 18.6 & -0.8 & 4.8 \\
\hline
\end{tabular}

Table 2: Main indicators of inflation in ASEAN

Many proponents of neoclassical economics believe in the existence of natural rate of unemployment in the labour market. The natural rate of unemployment could be defined as an equilibrium level of unemployment rate which would be determined by structural labour market imperfections, such as random movement of labour supply or demand, cost of finding a job or cost of moving from one job to another (Friedman, 1968). The natural rate of unemployment could be estimated by an estimation procedure suggested by Ball and Mankiw (2002). A basic relationship between inflation and unemployment could be expressed as (Ball and Mankiw, 2002):

$\pi=k-\alpha u$ 
where $\pi$ is inflation rate, $k$ is constant, $\alpha$ is slope parameter and $u$ is unemployment rate. This fundamental relationship could be modified by incorporating expectation. The expectationsaugmented relationship could be expressed as (Ball and Mankiw, 2002):

$\pi=\pi^{e}-\alpha\left(u-u^{*}\right)$

where $\pi^{e}$ is expected inflation rate and $u^{*}$ is natural rate of unemployment rate. Under the assumption of adaptive expectations, the expected inflation rate is equal the inflation rate in the past. The adaptive expectations-augmented relationship can be expressed as (Ball and Mankiw, 2002):

$\pi=\pi_{-1}-\alpha\left(u-u^{*}\right)$

where $\pi_{-1}$ is inflation rate at last period. This equation could be re-formulated to (Ball and Mankiw, 2002):

$\pi-\pi_{-1}=\alpha u^{*}-\alpha u$

For the purpose of econometric estimation, supply shock could be incorporated into this equation (Ball and Mankiw, 2002):

$\Delta \pi=\alpha u^{*}-\alpha u+v$

where $\Delta \pi$ is change in the inflation rate and $v$ is supply shock which is an error term in this equation. In other words, natural rate of unemployment rate could be estimated by regressing change in the unemployment rate $(\Delta \pi)$ on unemployment rate $(u)$ and an intercept $\left(\alpha u^{*}\right)$. The absolute value of intercept divided by slope parameter is the natural rate of unemployment rate.

Table 3 reported the estimated natural rate of unemployment or equilibrium unemployment rate in ASEAN countries. It should be noted that the natural rate of unemployment in five countries in mainland Southeast Asia are less than two percent. It means that these countries would enjoy lower unemployment rates in an equilibrium labour market where their labour demand is equal to their supply. Other ASEAN countries, except Brunei and Indonesia, would have moderate level of equilibrium unemployment rates which are less than 4 percent.

\begin{tabular}{|c|c|c|c|}
\hline Countries & $\begin{array}{c}\text { Slope parameter } \\
(\boldsymbol{\alpha})\end{array}$ & $\begin{array}{c}\text { Intercept } \\
\left(\boldsymbol{\alpha} \boldsymbol{u}^{*}\right)\end{array}$ & $\begin{array}{c}\text { Natural rate of } \\
\text { unemployment }\left(\boldsymbol{u}^{*}\right)\end{array}$ \\
\hline Brunei & 0.03 & -0.33 & 8.87 \\
\hline Indonesia & -0.11 & 0.86 & 7.32 \\
\hline
\end{tabular}




\begin{tabular}{|c|c|c|c|}
\hline Countries & $\begin{array}{c}\text { Slope parameter } \\
(\boldsymbol{\alpha})\end{array}$ & $\begin{array}{c}\text { Intercept } \\
\left(\boldsymbol{\alpha} \boldsymbol{u}^{*}\right)\end{array}$ & $\begin{array}{c}\text { Natural rate of } \\
\text { unemployment }\left(\boldsymbol{u}^{*}\right)\end{array}$ \\
\hline Cambodia & -0.99 & 1.48 & 1.57 \\
\hline Lao & 1.23 & -1.50 & 1.21 \\
\hline Malaysia & -3.31 & 4.34 & 3.41 \\
\hline Myanmar & -0.66 & 2.28 & 1.10 \\
\hline Philippines & -0.33 & 1.33 & 3.51 \\
\hline Singapore & -0.50 & 2.26 & 4.26 \\
\hline Thailand & -0.21 & 0.14 & 0.68 \\
\hline Vietnam & 0.90 & -1.66 & 1.78 \\
\hline
\end{tabular}

Table 3: Static natural rate of unemployment in ASEAN

It should be noted that there is a negative relationship between unemployment and inflation. For example, in the economic downturn, there would be a decrease in product demand which might cause a lower inflation rate. At same time, there would be a decrease in derived demand for labour which might cause a higher unemployment rate. By contrast, in times of economic boom, there would be an increase in product demand which might cause a higher inflation rate. At the same time, there might be an increase in the derived demand for labour which would cause a lower unemployment rate. This negative association between unemployment rate and inflation rate is known as the Phillips curve (Phillips, 1958). In the empirical analysis, there are two main types of Phillips curve, namely the traditional or baseline Phillips curve and the New Keynesian Phillips curve (Staiger et al., 1997; Gali and Gertler, 1999). The baseline Phillips curve could be expressed as (Staiger et al., 1997; Gali and Gertler, 1999):

$\pi_{t}=\kappa x+E_{t-1}\left(\pi_{t}\right)$

where $x$ is economic slack which is measure by a difference between actual output and natural rate of output or a difference between actual unemployment and natural rate of unemployment, $\kappa$ is slope parameter of the Phillips curve, $E_{t-1}\left(\pi_{t}\right)$ is expected current inflation rate. In the empirical analysis, an expected current inflation rate is considered to be equal to a lagged inflation rate or $\pi_{t-l}$. The New Keynesian Phillips curve could be expressed as (Staiger et al., 1997; Gali and Gertler, 1999):

$\pi_{t}=\kappa x+E_{t}\left(\pi_{t+1}\right)$

where $E_{t}\left(\pi_{t+1}\right)$ is expected future inflation rate. In the empirical analysis, country-specific inflation expectation is not available. So, researchers often use the realised inflation rate in the next period or $\pi_{t+1}$ as a proxy for the expectations of future inflation rate (Levy, 2019). The slope parameter in the Phillips curve (CV) and the New Keynesian Phillips curve (NKPC) in ASEAN countries are reported in Table 4. As the findings indicate, the slope coefficients in the PC are negative in all ASEAN countries, except Singapore, in line with theoretical negative association between lagged inflation rate and unemployment gap. The findings also indicate 
that the slope coefficients in the NKPC are positive in only four countries, namely Indonesia, Lao, the Philippines and Thailand, in line with the theoretical positive association between inflation rate in the next period and unemployment rate.

\begin{tabular}{|c|c|c|}
\hline Countries & $\begin{array}{r}\text { Slope parameter }(\boldsymbol{\kappa}) \\
\text { in PC }\end{array}$ & $\begin{array}{c}\text { Slope parameter }(\boldsymbol{\kappa}) \\
\text { in NKPC }\end{array}$ \\
\hline Brunei & -0.301 & -0.404 \\
\hline Indonesia & -0.077 & 0.232 \\
\hline Cambodia & -1.960 & -1.592 \\
\hline Lao & 2.521 & 1.103 \\
\hline Malaysia & -0.895 & -0.963 \\
\hline Myanmar & -7.172 & -10.683 \\
\hline Philippines & -0.568 & $2.875^{* *}$ \\
\hline Singapore & 0.332 & -0.605 \\
\hline Thailand & -0.574 & 0.163 \\
\hline Vietnam & -2.986 & $-4.191 *$ \\
\hline
\end{tabular}

Table 4: Phillips curve (PC) and New Keynesian Phillips curve (NKPC) in ASEAN

Notes: * indicates five percent significance level and ** indicates one percent significance level

Figure 3 depicts the time varying slope parameter in Phillips curve (PC) and New Keynesian Phillips curve (NKPC) in ASEAN-5 countries, namely Indonesia, Malaysia, the Philippines, Singapore and Thailand. The time-varying analysis of the PC revealed that there is a flattening of the Phillips curve in the Philippines and Thailand. In the case of the Philippines, the slope parameter of the PC increased from -4.450 in 2013 to -3.847 in 2014 , and further to -0.832 in 2017. Similarly, in the case of Thailand, the slope parameter of the PC increased from -1.414 in 2013 to -1.001 in 2015, and further to -0.201 in 2017. There is no flattening of the Phillips curve in Indonesia, Malaysia and Singapore. It should be noted that there is no flattening of the New Keynesian Phillips curve in all five ASEAN countries. 


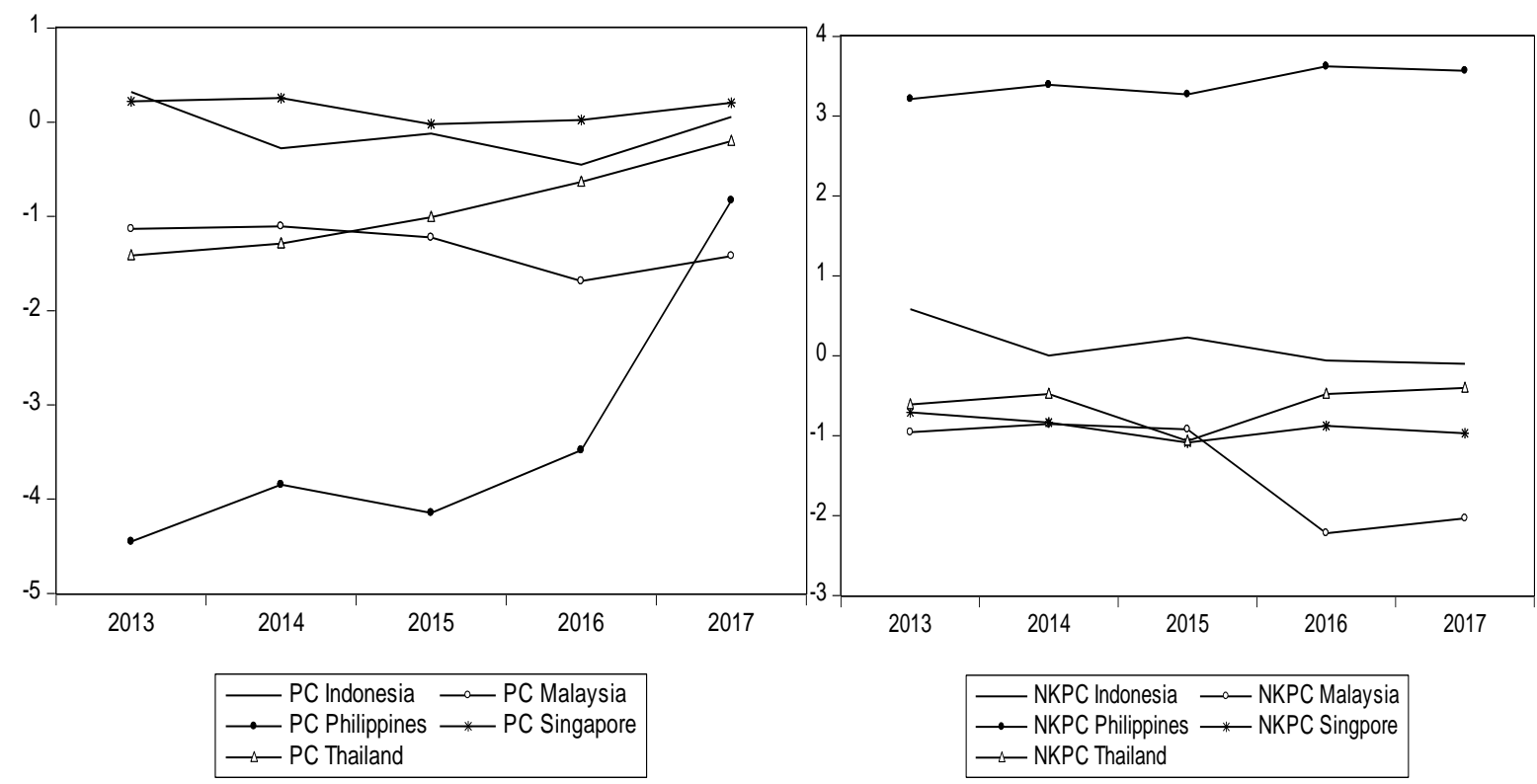

Figure 3: Time varying slope parameter in Phillips curve (PC) and New Keynesian Phillips curve (NKPC) in ASEAN-5

\section{Female workers in ASEAN}

Women in ASEAN have made significant progress in education attainment. Yet, their potential is not fully utilised especially in the workforce. A report from World Bank indicates that labour force participation rate for females above 15 years in ASEAN countries was 61 percent in September 2018, signalling a huge potential for future economic growth in the region (The ASEAN Post, 8 March 2019).

The female labour force participation rate in ASEAN countries as shown in Figure 4 ranges from 45 to 73 percent in 2017. Female labour force participation rate (FLFP) is the lowest in the Philippines (45.4 percent) and the highest in Cambodia (73.4 percent). Except for the Philippines and Thailand, most other countries experience an increase in the FLFP rate.

A low female participation rate represents a stock of underutilised labour where potential human capital in a society is restricted to household endeavours (Hirschman \& Aghajanian 1980). In general, employment and earnings can improve women's bargaining power in the household, which in turn is a tool to improve females and children's well-being (Klasen \& Pieters, 2015). 


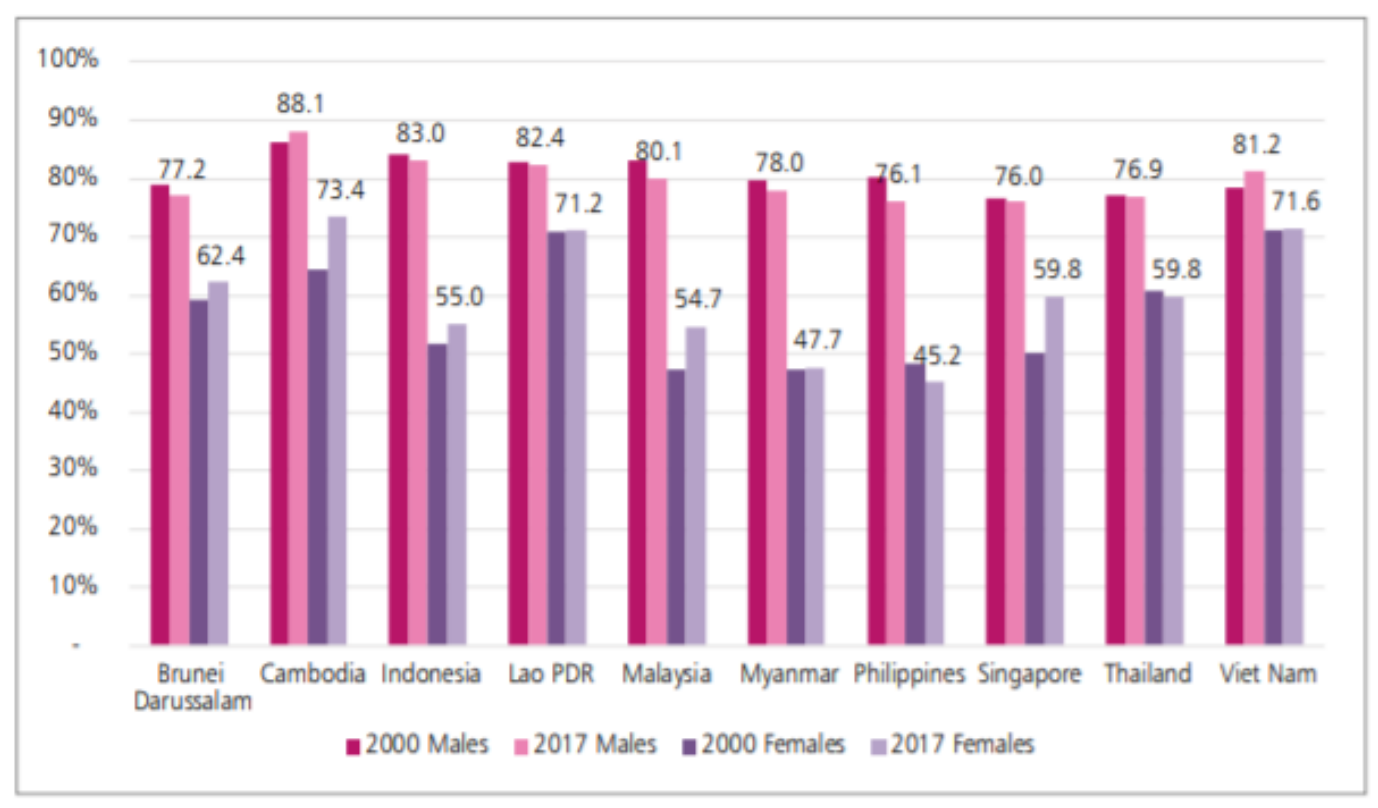

Figure 4: Labour force participation rate by gender (\%) for ASEAN countries, 2000 and 2017

Source: ASEAN Secretariat, ASEANstats database in ASEAN Key Figures 2018 (ASEAN 2018c: 24).

ASEAN countries are committed to promoting women's right at the regional and national level. All member states have ratified the Convention on All Forms of Discrimination Against Women (CEDAW) (ASEAN, 2016b:1). The Philippines ratified the Convention in 1981 followed by Lao PDR, Vietnam, Indonesia, and Thailand. In the 1990s, Cambodia, Malaysia, Singapore and Myanmar acceded to the Convention and finally Brunei Darussalam in 2006. However, women continue to face significant barriers to participation in the labour market including the unavailability of reliable and affordable childcare services.

The theory of female labour supply suggests that there is a strong negative correlation between the presence of children in a household and female labour supply. This relationship has been observed in many countries (Del Boca, Pasqua \& Pronzato 2005; Francesconi 2002; Mincer 1962; Moffitt 1984; Nakamura \& Nakamura 1994; Klasen \& Pieters 2015). However, the correlation between fertility and female labour force participation was positive in several OECD countries in the late 1980s (Del Boca \& Locatelli, 2006). This change was attributed to changes in work-family policies such as the introduction of parental paid leave and affordable childcare.

This suggests the importance of work-family policies in ASEAN countries. A lack of policies to reduce the potential opportunity costs of children, such as subsidised childcare, parental leave and child benefits may deter women from entering the labour market. In contrast, study in developing country such as Indonesia shows that a higher direct cost of children increases the pressure for women to work (Priebe, 2010). The presence of children may have both a negative and positive effects on maternal work. In view of the demographic transition in the ASEAN region, this transition can be converted into dividends if more women are encouraged to work (United Nations Development Programme, 2016: 56). The availability of quality and decent work for women is therefore important.

Women entering the labour market are disadvantaged in finding quality paid employment, forcing them to look to other sources of income, notably self-employment (OECD-ASEAN, 2017: 17). The self-employment rates for women in ASEAN is high, roughly 50 percent compared to an average of $13 \%$ in OECD countries (OECD-ASEAN, 2017). Women-owned 
businesses often lag behind male-owned enterprises in terms of size, productivity, and tend to be less profitable, with limited potential for expansion. They operated mainly in services such as catering, tailoring, beauty and food processing (OECD-ASEAN, 2017).

Targeted policies are crucial to drive further progress on women's entrepreneurial activities including to get better access to markets, finance sources, business support services as well as integration of ICT tools in their business operations (OECD-ASEAN, 2017:19). The $4^{\text {th }}$ Industrial Revolution will change the way of work and threatens the existence of most manual jobs. Therefore, entrepreneurial activities are expected to be the key alternative in empowering women in ASEAN.

\section{Elderly workers in ASEAN}

ASEAN countries are experiencing rapid population ageing where the percentage of older people has increased. The increasing percentage of older people aged 60 and above shown in Figure 5 shows that most of ASEAN countries will achieve the status of ageing nation by 2030 when $14 \%$ of their total population are people aged 60 and above.

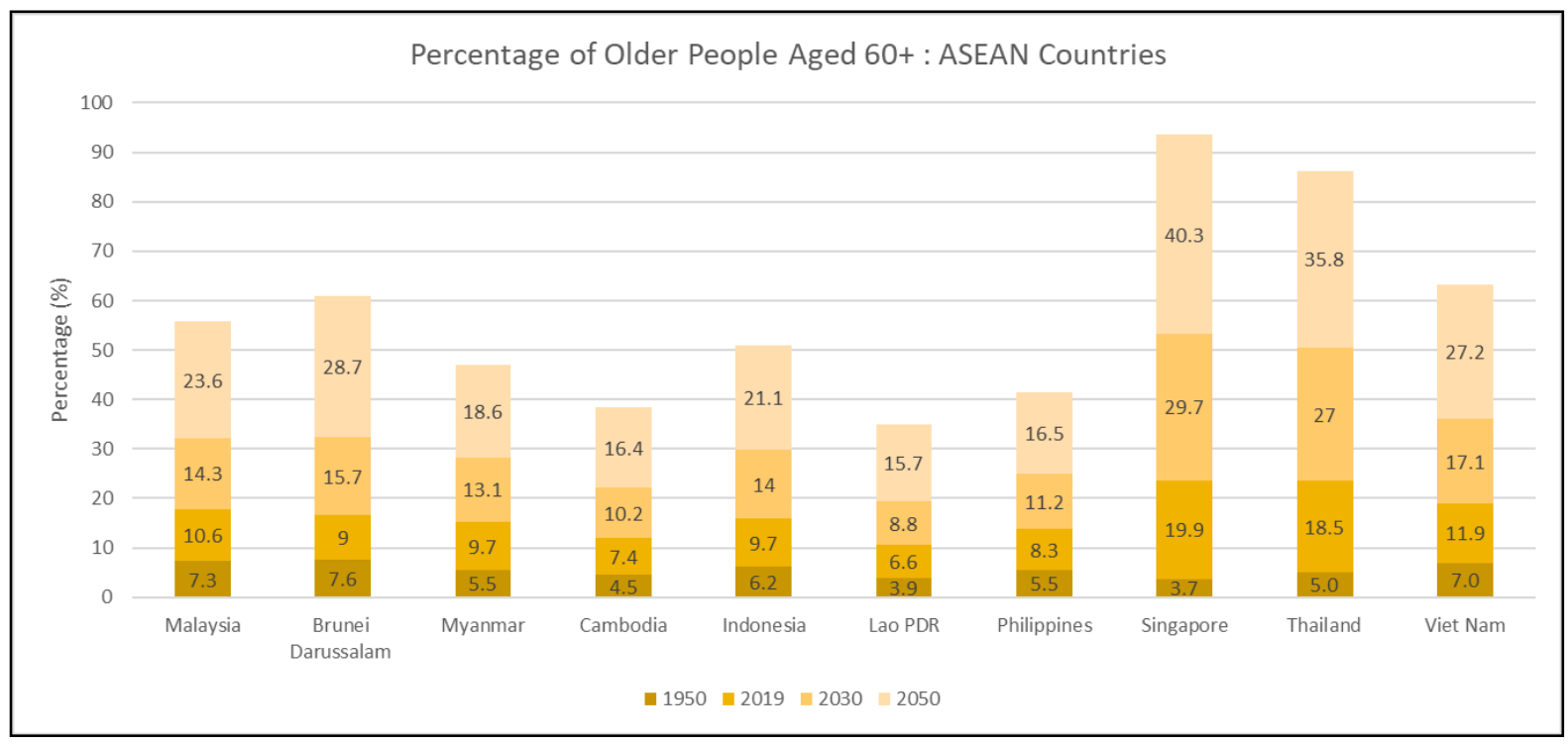

Figure 5: Percentage of older people aged 60 and above in ASEAN Countries

Sources: United Nations Population Division (2019)

This demographic change has led to various consequences on the social, economic and wellbeing of the society. The major repercussion of increasing ageing population on the labour market is its impact on working population: the decline in the share of working age population relative to children and older person. Based on the report by the World Bank, Thailand recorded the highest decline in working age population compared to any other ASEAN countries (World Bank, 2016). In Thailand, the working age population is expected to shrink by 11 percent as a share of the total population between 2016 and 2040 declines from 49 million people to 40.5 million people. The shrinking working age population can be detrimental to the growth of a country. For instance, the increase in the age group of 70-74 in Japan is associated with decreases in the GDP of Japan (Oliver, 2015). 
The negative perception of old age among society means that older people may face social exclusion, discrimination, and unequal treatment without adequate protection of their human rights (Chiesa, Zaniboni, Guglielmi, \& Vignoli, 2019). Previous literature found that older workers suffer from negative views and stereotype by employers at the workplace resulting to discrimination against older people in employment (Debrah, 1996). Study also showed that the enjoyment of human rights diminishes with age as being old is associated with lower productivity (Van Dalen, Henkens, \& Schippers, 2010) and slower to adapt to new technology (McCann \& Keaton, 2013). Nevertheless, the challenges brought about by ageing population in ASEAN should not be seen as a burden to the economy and organisation. While old age does not necessarily mean frailty and passive dependency, older people are a valuable asset as they have skills, experiences, wisdoms and knowledge which can be put to use for economic benefit through their continuous participation in the labour market (Vasconcelos, 2018). Despite older people's potentials and their contribution to the economy, however, in many ASEAN countries, this segment of society still tends to be excluded from the labour market.

Allowing older people to work could ensure their self-sufficiency in old age considering the long retirement duration older people may experience as a result of the increase in life expectancies. Moreover, public transfers are relatively low in many ASEAN countries where, people face insufficient funds leading to greater pressure to finance their consumption during old-age. However, compared to other advanced countries, the statutory retirement age across ASEAN countries are quite low for instance, 55-60 in Cambodia, 57 in Indonesia, and 60 in Brunei, Laos, Malaysia, Myanmar, the Philippines, Thailand and Vietnam (OECD, 2018).

Thus, the increasing number of older people and the preparation for ageing workforce has aroused interest among policymakers with regards to the right of older people in ASEAN specifically in promoting decent work, equal employment and non-discrimination in the labour market. This is in line with the objectives of the Madrid International Plan of Action on Ageing (MIPAA), which ensures that people can age with security and dignity through continuous participation in their societies as citizens with full rights. Aligned with MIPAA, 2030 Agenda for Sustainable Development has also focus on reducing inequality and reaching all population groups, especially those furthest behind by promoting full and productive employment and decent work for all.

Regionally, ASEAN has established the ASEAN Intergovernmental Commission on Human Rights in 2009 in its effort to promote human rights among the 10 ASEAN countries. As a result, ASEAN Human Rights Declaration was adopted which affirms that human rights belong to every person including older people (ASEAN, 2013b). Older people have the right to a dignified and decent work, to equal opportunity and treatment on the same terms as other workers which includes practices on wages, hours of work, occupational safety and health, recruitment processes, treatment in workplace and inclusion of older people in the decisionmaking processes (ASEAN Trade Union Council, 2016).

At the national level, several governments introduced legislations pertaining to the right of older persons to equal treatment and non-discrimination. The legislation is listed in Table 5.

\begin{tabular}{|l|l|l|}
\hline Country & Legislation & Highlight \\
\hline Myanmar & Elders Law (2016) & $\begin{array}{l}\text { Health and well-being, social } \\
\text { pensions, care of older persons, } \\
\text { prevention of discrimination } \\
\text { and abuse }\end{array}$ \\
\hline
\end{tabular}




\begin{tabular}{|c|c|c|}
\hline Country & Legislation & Highlight \\
\hline Thailand & National Pension Act (2017) & $\begin{array}{l}\text { Ensure that income security in } \\
\text { old age is guaranteed as a basic } \\
\text { human right, and to strengthen } \\
\text { the old age pension }\end{array}$ \\
\hline Singapore & $\begin{array}{l}\text { Retirement and Re- } \\
\text { employment Act }\end{array}$ & $\begin{array}{l}\text { Employees who turn } 62 \text { can } \\
\text { continue to be employed in the } \\
\text { organisation if they meet the } \\
\text { eligibility criteria of re- } \\
\text { employment }\end{array}$ \\
\hline Viet Nam & Law on the Elderly (2010) & $\begin{array}{l}\text { Activities of promoting the } \\
\text { elderly's role }\end{array}$ \\
\hline
\end{tabular}

Table 5: National legislation pertaining to the rights of older people.

Removal of barriers and obstacles which serve to exclude and discriminate older people in workforce should be practiced among ASEAN countries in promoting employment opportunities for all in ways appropriate to their age and capabilities. Among ASEAN countries, Singapore is on the lead in preparing their ageing workforce with various measures including legislations and programmes for older workers. In Singapore, the minimum retirement age is 62. Based on the Retirement and Re-employment Act, it is a must for employers to offer reemployment to their employee upon reaching 62 of age to continue working until the age of 67 . On $1^{\text {st }}$ July 2012, the re-employment age was raised from 65 to 67 for older workers who wish to work. This age-friendly employment policy by eliminating age barriers is both timely and indispensable to be adopted in other ASEAN countries as it could ease the fiscal pressure on pension schemes and health care systems.

Policymakers in ASEAN countries should emphasize in promoting decent work to older people with flexible employment which includes flexible working hours and working condition. This can be implemented in the workplace by providing and matching suitable work scopes with older workers' potential and physical conditions. Flexible working hours could ensure that older people could work within their health limitations and physical capacity. ASEAN can learn from other countries as such flexible work environment becomes the reason for many individuals in most high-income countries to be able to continue working in old age and attain work enjoyment (Choi, Ospina, Steger, \& Orsi, 2018).

A growing number of countries have started exploring various options to encourage older people to keep active in the labour market. The majority of older people in ASEAN countries such as in Thailand, Vietnam and Malaysia are working in agriculture sector, mostly concentrated in rural areas (Adhikari, Soonthorndhada, \& Haseen, 2011; Thanh Long \& Thi Ly, 2015; Wan Ahmad, Ismail, \& Rahman, 2011). Expanding the sectors where older people can work may be an option in ASEAN countries by encouraging various income-generating opportunities for older persons. For instance, Malaysia has introduced the Silver entrepreneurship, a strategic initiative in encouraging older people and retirees to embark into entrepreneurial career (Ahmad, Nasurdin, Halim, \& Taghizadeh, 2014). Expanding employment opportunities could increase the income-generating potential among older people thus reducing their vulnerability in the society.

In sum, the greying workforce will pose various challenges especially in the formulation of labour market policies in ASEAN. Many ASEAN countries are still lacking in terms of legislations pertaining to protecting older people's rights in the labour market. Proper policies, 
legislation and mechanism of ensuring equality and promote employment for all should be in place. The opportunity for continued and active participation among older people in the labour market with provisions of viable employment options will ensure that older people can live in dignity, security and with full rights.

\section{Workers with disabilities}

On 7 November 2011, ASEAN leaders made a landmark declaration the ASEAN decade of people with disability 2011-2012 in Bali, Indonesia. In this special decade for person with disabilities, ASEAN countries promised to make serious efforts to promote rights and opportunities for the persons with disabilities in all area of its society, including labour market in ASEAN. This declaration is known as the Bali Declaration on the enhancement of the role and participation of persons with disability. There are twenty-five specific clauses in the Bali Declaration. For example, clause 11 of the Bali Declaration proclaims that ASEAN countries shall develop a social service to support the persons with disabilities in the field of employment. Clause 15 of the Bali Declaration emphasize on the need of providing accessibility for public facilities, public transportation and employment for persons with disabilities (ASEAN, 2013).

At same time, ASEAN countries also adopted an action plan for the promotion of rights and opportunities for the person with disabilities in Bali, Indonesia. This action plan is known as the Mobilisation Framework of the ASEAN decade of persons with disabilities. The basic aim for this framework is to promote disability inclusive development in ASEAN countries. There are fifteen specific priority areas in this action plan. For instance, in the third priority area of the Mobilisation Framework, ASEAN countries promised to promote employment and decent work among persons with disabilities. In this priority area, there are five specific action plans for the promotion of employment for the person with disabilities. Firstly, ASEAN countries would promote employment for the person with disabilities in the public sector. Secondly, ASEAN countries would encourage private companies for the employment for the person with disabilities under the name of corporate social responsibilities (CSR). Thirdly, ASEAN countries would create a social network among the persons with disabilities. Fourthly, ASEAN countries would conduct skill development program for the person with disabilities. Finally, ASEAN countries would make efforts to build capacities of disabilities (ASEAN, 2013).

Besides official ASEAN declaration, some ASEAN countries made serious efforts to promote the employment for the persons with disabilities by enacting laws against discrimination or introducing quota system. Some ASEAN countries have enacted specific law for the persons with disabilities. For example, Philippines enacted a milestone law on the persons with disabilities in 1972. This important law is known as the Act providing for the Rehabilitation, Self-development and Self-reliance of Disabled Person. All kind of discrimination against the person with disabilities are prohibited under this act (O'Reilly, 2003; ILO, 2015). Furthermore, some ASEAN countries introduced a quota system to promote the employment for persons with disabilities. According to the International Labour Organization (ILO), there are seven Asian countries that introduced a quota system for the promotion of employment among the persons with disabilities, ${ }^{3}$ including two ASEAN countries, namely the Philippines and Thailand (ILO, 2015). For example, Thailand introduced a quota system under the Rehabilitation of Persons with Disabilities Act in 1991. Under the law, a 0.5 percent quota for workers with disabilities was introduced and one disabled worker per 200 workers should be

\footnotetext{
${ }^{3}$ Nine countries which introduced quota system for persons with disabilities are China, India, Japan, Mongolia, the Philippines, Sri Lanka and Thailand.
} 
employed in any firm. The tax deduction system is also introduced to promote the quota system (Sumitomo Foundation, 2019).

\title{
Conclusion
}

The promotion and protection of human rights is a fundamental principle of the ASEAN Community. In order to realise this crucial principle, all ASEAN member states have made efforts to promote human rights and freedom of all ASEAN citizens, including the disadvantaged workers. The findings from current study could be summarized into two main facts. Firstly, the unemployment rates in five ASEAN countries, namely, Cambodia, Lao, Myanmar, Thailand and Vietnam, are relatively low. By contrast, two ASEAN countries, such as Brunei and Indonesia, still suffer from high unemployment. Under these labour market situations, disadvantaged workers in these countries may face a serious problem of unemployment. Secondly, ASEAN has made serious commitment for the promotion of employment among disadvantaged workers, for example, the ASEAN commission on promotion and protector of the rights of women and children was set up in 2010. In order to promote a concept of "productive ageing", ASEAN also adopted the ASEAN strategic framework on social welfare and development in 2015. For the promotion of employment for persons with disabilities, ASEAN leaders declared the ASEAN decade of people with disabilities 2011-2012 in Bali Indonesia. Thirdly, individual ASEAN countries also made serious efforts to promote employment of disadvantaged workers. For example, the Philippines enacted an act for self-development and self-reliance of person with disabilities and all kind of discrimination against persons with disabilities are prohibited under this act. Thailand introduced a quota system for workers with disabilities under the Rehabilitation of Persons with Disabilities Act in 1991.

There are two recommendation for policymakers in ASEAN countries. Firstly, some ASEAN countries still suffer from high unemployment problem. The policymakers in ASEAN countries may make concerted efforts to promote employment and reduce unemployment in ASEAN, especially among disadvantaged workers. Secondly, only two ASEAN countries introduced a quota system to promote employment for persons with disabilities. The policymakers in ASEAN countries may consider introducing a systematic and uniform quota system in ASEAN. As this paper focuses on three groups of disadvantaged workers, namely female workers, elderly workers and workers with disabilities future study may consider other groups of disadvantaged workers, such as minority workers or foreign workers. The findings from these studies may offer great insights on employment for all in ASEAN.

\section{References}

Adhikari, R., Soonthorndhada, K., \& Haseen, F. (2011). Labor force participation in later life: Evidence from a cross-sectional study in Thailand. BMC Geriatrics, 11. https://doi.org/10.1186/1471-2318-11-15.

\author{
Ahmad, N. H., Nasurdin, A. M., Halim, H. A., \& Taghizadeh, S. K. (2014). The Pursuit of \\ Entrepreneurial Initiatives at the "Silver" Age: From the Lens of Malaysian Silver \\ Entrepreneurs. Procedia - Social and Behavioral Sciences, 129, 305-313. \\ https://doi.org/10.1016/j.sbspro.2014.03.681
}

ASEAN (2013a). Bali Declaration on The enhancement of the role and participation of the persons with disabilities. [accessed on 16 March 2019] https://asean.org/?static_post=bali- 
declaration-on-the-enhancement-of-the-role-and-participartion-of-the-persons-withdisabilities-in-asean-community.

ASEAN. (2013b). ASEAN Human Rights Declaration and Phnom Penh Statement on the Adoption of the ASEAN Human Rights Declaration. [accessed on 16 March 2019] www.asean.org.

ASEAN (2014). ASEAN Human Rights Declaration. [accessed on 16 March 2019] https://www.asean.org/storage/images/ASEAN_RTK_2014/6_AHRD_Booklet.pdf.

ASEAN (2015). ASEAN Strategic Framework for Social Welfare. [accessed on 16 March 2019] https://asean.org/storage/2012/05/11-ASEAN-Strategic-Framework-on-SocialWelfare.pdf.

ASEAN. (2016a). ASEAN women are a potential boost to the region's labour force and economy. [accessed on 30 October 2019]. https://asean.org/asean-women-are-a-potentialboost-to-the-regions-labour-force-and-economy/

ASEAN. (2016b). Progress report on women rights and gender equality. [accessed on 30 October 2019]. https://asean.org/storage/2012/05/Progress-Report_Women-Rights-andGender-Equality.pdf

ASEAN (2018a). ASEAN Enabling Masterplan 2025. [accessed on 16 March 2019]. https://asean.org/storage/2018/11/ASEAN-Enabling-Masterplan-2025-Mainstreaming-theRights-of-Persons-with-Disabilities.pdf.

ASEAN (2018b). ACWC Work Plan for 2016-2020. [accessed on 16 March 2019] https://asean.org/storage/2019/01/37.-December-2018-The-ASEAN-Commission-on-thePromotion-and-Protection-of-the-Rights-of-Women-and-Children-ACWC-Work-Plan2016-2020.pdf.

ASEAN. (2018c). ASEAN Key Figures 2018.

ASEAN (2019). ACWC Progress Report on women's human rights and gender equality. [accessed on 16 March 2019] https://asean.org/?static_post=progress-report-womens-rightsgender-equality.

ASEAN Trade Union Council. (2016). Strengthening and Harmonizing Labour Standards in ASEAN.

Ball, L. \& Mankiw, N.G. (2002). The NAIRU in theory and practice. Journal of Economic Perspectives, 16(4), 115-136.

Chiesa, R., Zaniboni, S., Guglielmi, D., \& Vignoli, M. (2019). Coping with negative stereotypes toward older workers: Organizational and work-related outcomes. Frontiers in Psychology, 10(March), 1-9. https://doi.org/10.3389/fpsyg.2019.00649

Choi, E., Ospina, J., Steger, M. F., \& Orsi, R. (2018). Understanding work enjoyment among older workers: The significance of flexible work options and age discrimination in the workplace. Journal of Gerontological Social Work, 61(8), 867-886. https://doi.org/10.1080/01634372.2018.1515140

Debrah, Y. A. (1996). Tackling age discrimination in employment in Singapore. International Journal of Human Resource Management, 7(4), 37-41. https://doi.org/10.1080/09585199600000157

Del Boca, D, Pasqua, S \& Pronzato, C. (2005). Fertility and employment in Italy, France, and the UK. Labour, 19, Special Issue, 51-77. 
Del Boca, D \& Locatelli, M. (2006). The determinants of motherhood and work status: a survey. IZA Discussion Paper No. 2414.

Francesconi, M. (2002). A joint dynamic model of fertility and work of married women. Journal of Labor Economics, 20(2), 336-380.

Friedman, M. (1968). The role of monetary policy American Economic Review, 58(1), 1-17.

Hirschman, C \& Aghajanian, A. (1980). Women's labour force participation and socioeconomic development: the case of Peninsular Malaysia, 1957-1970. Journal of Southeast Asian Studies, 11(1), 30-49.

International Labour Organization (2015). Decent work for persons with disabilities. [accessed on 16 March 2019]. https://www.ilo.org/wcmsp5/groups/public/---ed_emp/--ifp_skills/documents/publication/wcms_430935.pdf

International Labour Organization (2019). Quick guide on interpreting the unemployment rate. [accessed on 16 March 2019]. https://ilo.org/wcmsp5/groups/public/---dgreports/--stat/documents/publication/wcms_675155.pdf

Gali, J. \& Gertler, M. (1999). Inflation dynamics: A structural econometric analysis. Journal of monetary Economics, 44(2), 195-222.

Klasen, S \& Pieters, J. (2015). What explains the stagnation of female labor force participation in urban India? World Bank Economic Review, 29(3), 449.

Levy, A. (2019). The euro area Phillips curve: Identification with regional data. mimeo [accessed on 16 March 2019]. http://economics.mit.edu/grad/levya/research1.

McCann, R. M., \& Keaton, S. A. (2013). A Cross Cultural Investigation of Age Stereotypes and Communication Perceptions of Older and Younger Workers in the USA and Thailand.

Educational Gerontology, 39(5), 326-341. https://doi.org/10.1080/03601277.2012.700822

Mincer, J. (1962). Labor force participation of married women: a study of labor supply in Universities-National Bureau Committee for Economic Research (ed.), Aspects of Labor Economics, Princeton University Press, Princeton, 63-105.

Moffitt, RA. (1984). The effects of grants-in-aid on state and local expenditures. Journal of Public Economics, 23(3), 279.

Nakamura, A \& Nakamura, M. (1994). Predicting female labor supply: effects of children and recent work experience. Journal of Human Resources, 29(2), 304-327.

OECD. (2018). Pensions at a Glance Asia/Pacific 2018. https://doi.org/10.1787/pension_asia2018-en.

OECD-ASEAN. (2017). Strengthening women's entrepreneurship in ASEAN: Towards increasing women's participation in economic activity. Paris: OECD. [accessed on 30 October 2019]. https://www.oecd.org/southeast-asia/regionalprogramme/Strengthening_Womens_Entrepreneurship_ASEAN.pdf

O'Reilly, A. (2003). The right to decent work of persons with disabilities. IFP Working Paper No. 14.

Oliver, M. (2015). Population ageing and economic growth in Japan. 35(11), 841-863. https://doi.org/10.1108/IJSSP-02-2015-0018.

Phillips, A. W. (1958). The relation between unemployment and the Rate of change of money wage rates in the United Kingdom 1861-1957. Economica, 25(100), 283-299. 
Priebe, J. (2010). Child costs and the causal effect of fertility on female labor supply: an investigation for Indonesia 1993-2008, CRC-PEG Discussion Paper No. 45, University of Göttingen, [accessed on 16 March 2019].

www.iza.org/conference_files/worldb2011/priebe_j3393.pdf

Staiger, D.O., Stock, J.H., \& Watson, M.W. (1997). How precise are estimates of the natural rate of unemployment? In Romer, C.D. \& Romer, D.H. Reducing inflation: Motivation and strategy. Chicago: University of Chicago Press, pp.195-246.

Sumitomo Foundation. (2019). Comparative study on vocational rehabilitation of persons with physical disabilities in Japan and Thailand. [accessed on 16 March 2019].

http://www.sumitomo.or.jp/e/sub/jare01e-rep40.htm.

Thanh Long, G., \& Thi Ly, L. (2015). Determinants of Labor Force Participation of Older People in Vietnam. Journal of Economics and Development, 17(2), 29. Retrieved from http://www.vjol.info/index.php/KTQD/article/viewFile/21759/18593

United Nations (2006). Convention on the Rights of Persons with Disabilities. [accessed on 16 March 2019] https://www.un.org/development/desa/disabilities/convention-on-the-rights-ofpersons-with-disabilities.html.

United Nations Development Programme. (2016). Asia-Pacific Human Development Report: Shaping the future: How changing demographics can power human development. [accessed on 30 October 2019].

http://hdr.undp.org/sites/default/files/rhdr2016-full-report-final-version1.pdf

United Nations Population Division. (2018). World Population Prospects (2019). [accessed on 16 March 2019]. https://population.un.org/wpp/Download/Standard/Population/

Van Dalen, H. P., Henkens, K., \& Schippers, J. (2010). Productivity of older workers: Perceptions of employers and employees. Population and Development Review, 36(2), 309-330. https://doi.org/10.1111/j.1728-4457.2010.00331.x

Vasconcelos, A. F. (2018). Older workers as a source of wisdom capital: Broadening perspectives. Revista de Gestão, 25(1), 102-118. https://doi.org/10.1108/rege-11-2017-002

Wan Ahmad, W. I., Ismail, Z., \& Rahman, A. A. (2011). Aging and Economic Participation of Older Population in Rural Malaysia. International Journal of Humanities and Social Science, 1(9), 128-133.

World Bank. (2016). Thailand Economic Monitor: Aging Society and Economy. [accessed on 16 March 2019]. https://doi.org/10.1371/journal.pbio.1001524 